\title{
Regional Dimension in Knowledge Production in Hungary
}

\section{Summary}

Knowledge flow is described by two contradicting theories. One of them claims that knowledge can only be put in practice if in addition to written elements, its tacit parts can also be transferred. This is why proximity and a common culture matter, and RDI (research, development and innovation) intense activities tend to spatially concentrate. According to the other theory, governmental RDI expenditure is a good way to reduce regional gaps. In this paper EU's Horizon 2020 research funding framework data is analysed and efforts are made at deciding which theory is confirmed by them. Should the leaders in innovation have a different RDI policy than those with poorer RDI results? An overview is given of the main policy debates that form and influence national and supranational research, development and innovation policy frameworks and subsidising systems. The current state of the Hungarian RDI sector is described and conclusions are drawn on subsidisation policy in light of the H2020 data.

Journal of Economic Literature (JEL) codes: D7, D83, O3

Keywords: innovation, research and development, regional development, knowledge, case study, Hungary

Endre SPALLER, vice president of the Governmental Information Technology Development Agency, former president of the National Innovation Office, Hungary (spaller.endre@kifu.gov.hu); DR LÁszLó VASA, research professor, Széchenyi István University, Hungary (laszlo.vasa@ifat.hu). 
Endre Spaller, László Vasa: Regional Dimension in Knowledge Production...

\section{INTRODUCTION}

Innovation has been completely rearranging the world economy (e.g. Romano and Trau, 2017). Even if a country does not keep pace with innovation, it cannot fend off the adverse effects of development, but it will be unable to enjoy its advantages. That is why countries spend an increasing amount of money on innovation. Below is a summary of the main policy debates on RDI funding.

Approximately USD 1,600 billion is spent a year on funding $\mathrm{R} \& \mathrm{D}$, including corporate $\mathrm{R} \& \mathrm{D}$, in the world. However, it is difficult to relate genuine business profit to these funds. Funding is one of the major instruments accessible to governments for steering science and innovation systems. Governments spend a lot of public money on sustaining a wide academic sector. Initially, the authors of this study presumed that project evaluation is a fine-tuned tool in the service of economic growth. But the first research which tried to develop new indicators on pre-existing databases was conducted merely a decade ago.

The evaluation of the publicly funded corporate RDI programmes often contains a theory of "other benefits" or "social benefits". It seems natural even in high-level policy papers to evaluate the corporate R\&I programmes on terms other than the benefit produced for the beneficiary. Is not future profitability the key evaluation criterion in most cases?

The consequence is an interesting contradiction. Although all programmes are evaluated as highly successful, and the impact on GDP seems to be very high, overall, the funding schemes are considered as insufficiently effective. For this reason, the policy-makers focus on refundable sources, and financial instruments gain increasing ground. From our perspective this is a bypass, an effort at circumventing the problem instead of penetrating into it and reorganising it.

Governments provide support of a level of 10-20 per cent of business R\&D expenditures in most OECD countries. The role of the state is likely to remain stable in this regard in the next 10-15 years. However, national and regional governments have a growing economic pressure to reduce public expenditure which may affect their role in the $\mathrm{R} \& \mathrm{D}(\mathrm{OECD}, 2016)$. On the contrary, the rising number of interstate conflicts, and its expanding into technological fields may be a trajectory for further state involvement into sponsoring private $\mathrm{R} \& \mathrm{D}$. So if policy makers aim to stimulate and accelerate (or just maintain) economic growth and development with strengthening research, development and innovation, then just spending more money will not be enough. Something will be needed that converts quantity into quality and this could be the export-oriented approach, or in the field of research it is the participation in international research collaborations and networks.

Knowledge flow is described by two contradicting theories. One of them claims that knowledge can only be put in practice if in addition to written elements, its tacit parts can also be transferred. This is why proximity and a common culture matter, and RDI (research, development and innovation) intense activities tend to spatially concentrate. According to the other theory, governmental RDI expenditure is a good way 
Civic Review · Vol. 16, Special Issue, 2020

to reduce regional gaps. In this paper EU's Horizon 2020 research funding framework data is analysed and efforts are made at deciding which theory is confirmed by them. Should the leaders in innovation have a different RDI policy than those with poorer RDI results? An overview is given of the main policy debates that form and influence national and supranational research, development and innovation policy frameworks and subsidising systems. The current state of the Hungarian RDI sector is described and conclusions are drawn on subsidisation policy in light of the H2020 data.

\section{POLIGY DEBATES ON R\&D FUNDING}

A country achieves long-term growth if it invests in human capital, knowledge or innovation. These resources have a spill-over effect and they spread through out of the entire economy and contribute to the growth (Romer, 1990; Jones, 1995, p. 761) criticises Romer for the implication of a "scale effect" in his model. This means that an increase in resources of RDI (money, personnel, etc.) should increase the level of growth. This is not true, however several countries look like behaving so.

What policy makers expect from RDI funds is to have impact on GDP growth (Shibata et al., 2008; Macilwain, 2010). Public RDI policies are not directly attached to GDP growth expectations, however these expectations are lying behind these policies.

Public RDI policies are justified by market failures, positive spill-overs and negative externalities (EC, 2017b). "The standard market failure rationale for business RDI support is that firms tend to underinvest in RDI on account of its costs and uncertainty, the time required to obtain returns on investment, and the possibility that competitors can capture knowledge spill-overs" (OECD, 2016). Vanino et al. (2019) summarise the rational for public support to company's RDI activities. The main reason is that it has an effect on knowledge and value creation. He identified four mechanisms:

1. Public support will increase liquidity and financial slack

2. Through cost-sharing, it reduces the required investment and de-risks private investment

3. Where there is a market failure innovation may have market-making objectives to address particular social or economic challenges

4. Public R\&D and innovation support can play an enabling or bridging role, helping firms to access otherwise unavailable new or pre-existing knowledge.

GDP growth is a positive spill-over from this point of view. The Lamy report (EC, $2017 \mathrm{~b}$ ) says that EU is not good at commercialisation of research while another EU document states that every euro spent generates 10-30 per cent benefit (see also Hather et al., 2010). Here arises the problem of impact assessment. Bornmann (2013, p. 219) collects the problem of impact assessment, and he concludes that it is impossible to measure correctly the impact of a research, thus it is impossible to show it to the policy makers.

Following the economic crisis in 2008, many governments reinvented the targeted industrial policy. Concerns about the loss of manufacturing capacities, growing competition from emerging economies, and a sciences and technology-driven new produc- 


\section{Endre Spaller, László Vasa: Regional Dimension in Knowledge Production...}

tion revolution have contributed to a surge in interest (OECD, 2016). Concerns about losing something important or falling behind the competitors are rationale in RDI investments as well. This argument relates RDI funding to economic growth again.

While GDP growth expectations are obvious regarding the RDI funding, some research show that the connection is not linear (Jaruzelski et al., 2005) researched the thousand publicly owned companies that spent the most for RDI. They found no connection between the high RDI expenditure and the value of company or income or any success indicator. You cannot buy results for money. But exactly this is what funding agencies are trying: they try to convert state fund to RDI results and profit. This process is not that simple.

There are three big ways of reforming innovation expenditure in a way that are thought to be more effective:

- giving refundable fund instead of the non-refundable,

- changing the funding schemes, and the eligibility criteria,

- changing the decision-making process.

With the refundable sources you reach more mature companies and innovation ideas, than with the non-refundable ones. Both have their own role in the innovation landscape. Policy makers however tends to believe that non-refundable sources are less effective. So they turn to refundable sources, as those provide easy answer on profitability. The other two is always an issue to fine-tune the RDI system.

Thus governments' main reason to support RDI is that they hope to have some economic impact. If a policy maker aims to increase economic growth through research and innovation, then just spending more money is not enough, because better economies sweat better projects. After a while, spending more money will reach not viable projects. This is the theoretical question that we test here.

As a summary, there are three main questions:

- What to expect from R\&D funding: economic growth or spill-over effects? (We were already talking about this topic.)

- Is this expectation directly linked to the RDI system, or it just appears indirectly? (We were already talking about this topic.)

- How can the governments reach this goal? (This is in the following chapters.)

\section{TWO CONTRADICTING THEORIES IN THE REgIONAL STUDIES}

Is RDI industry a good tool for regional development?

"Innovative activity is not uniformly or randomly distributed across the geographical landscape. Indeed, the more knowledge-intensive the economic activity, the more geographically clustered it tends to be. This tendency toward spatial concentration has become more marked over time, not less. [...] This reality contradicts a longstanding prediction that the increasing use of information communication technology would lead to the dispersal of innovative activity over time. [...] When everyone has relatively easy access to explicit/codified knowledge, the creation of unique capabilities and products depends on the production and use of tacit knowledge" (Asheim and Gertler, 2005). 
Civic Review · Vol. 16, Special Issue, 2020

Tacit knowledge is a key element to understand the importance of spatial proximity. Tacit knowledge is the context, institutional context in which codified knowledge was born. It can be transmitted through face to face interaction between partners who already share some basic knowledge and trust and maybe like each other. Thus, it is hard to sell over long distances. "The skills required for effective knowledge transfer within collective learning process are highly time- and space-specific." Lengyel (2010) has found that the common culture, societal and technological proximity enhances the spread of innovation. The innovation system of a company is collaboration between different actors, such us universities, research institutes, other companies in the value chain, public agencies. The geographic dispersion of these institutions is also not even, so socially organized learning process is not possible everywhere, as there are no partners to learn from.

In the last decade the success of cities became to the centre of regional research (Filep, 2014; Rechnitzer et al., 2019). RDI is typically present in the cities. Bigger cities are more likely to have some RDI industry. RDI industry is concentrating in hubs, and these hubs need a critical mass which is present only in the cities. Smart is a city if it is technologically leading, there are working a lot of researchers, there is a lot of early users, innovation is part of the city culture. Other studies state as well that behind the success of the developed countries there is a spatial concentration (Filep et al., 2012; Szirmai, 2005).

$\mathrm{R} \& \mathrm{D}$ is thought to be a good tool to reduce regional gaps. EU describes the development with three words: intelligent, sustainable, and inclusive (Europe 2020). Intelligent includes $\mathrm{R} \& \mathrm{D}$, knowledge production, high value added. The EU takes special attention to this topic as part of its growth strategy. The RDI budget of Horizon Europe will be higher with 50 per cent than the Horizon 2020. The European Regional Development Fund also includes priorities on RDI, as a tool of reducing regional inequalities. Some scientist (e.g. Chandra et al., 2010) also states that the innovation guaranties stable growth and thus predictable welfare. The progress of science and technology is a main driver of sustainable long-term growth (Guan et al., 2016, p. 770).

The theory of intraregional development recognized that for the sustainable economic development it is necessary the existence of stimulating institutions such as universities, research institutions, corporate innovation centres and the well-established supplier's network (Rechnitzer, 1994).

So, there are two contradicting arguments. One argues that the knowledge is local, so it is hard if possible at all to raise $\mathrm{R} \& \mathrm{D}$ intensity in a region just by providing funds. The other argues that if we create opportunities through funding, more and more people will take the opportunity.

\section{HORIZON 2020 DATA THROUGH THE THEORETICAL LENSES}

Wealthier countries, countries with good economy have better projects that allure with better results. 


\section{Endre Spaller, László Vasa: Regional Dimension in Knowledge Production...}

Is it true, that better economies have better RDI projects? This question was tested among EU MMember States. This would mean that if the knowledge industry is less developed then the RDI funding should be different. If better economy sweats better projects, it is easier to find the best ones. If you have more money than good projects, then you fund some of the average projects with higher risk.

The European Innovation Scoreboard (EIS) measures the innovation performance of the Member States. It is composed by four sets of indicators: framework conditions, investments, innovation activities, impacts. Countries are divided into four groups based on EIS scores: innovation leaders, strong innovators, moderate innovators, modest innovators.

Horizon 2020 finance excellent research. In each country the best projects are submitted to EU level, as it gives a higher prestige, an immediate international environment and a larger innovation network. At the EU level the competition is stronger, and the per cent of selected projects is uneven across countries. We can measure the ability of a country to find out good projects by looking at the per cent of the contracted projects. If we compare EIS scores with Horizon 2020 success rate, we get the supposed result.

Figure 1: EIS scoreboard vs. the ratio of retained projects in H2O2O

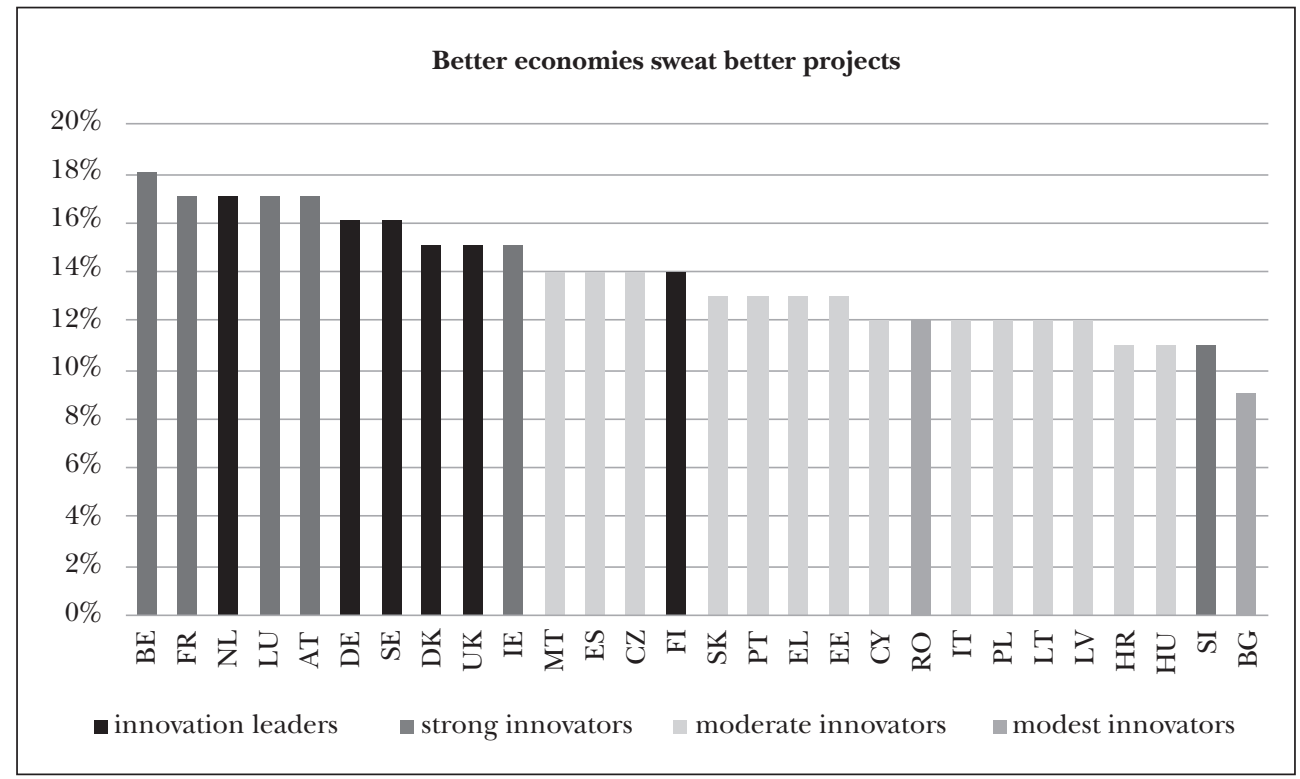

Source: Corda

Figure 1 compares the success rate in Horizon 2020 (2014-2016) and indicates the country ranking in European Innovation Scoreboard (2017). Clearly, the more innovative the economy is the better chances it has to submit good projects.

Are these better economies able to earn more money with these better projects? Reading the Fab-Lab-App (EC, 2017b) the RDI output indicators in the EU are worse 
than we can expect from the input indicators. We invest a lot in RDI but we earn very few on it. It means that something is wrong with the policy making. We measure something else that we want, and we make connections between datasets incorrectly.

There are three reasons why the EU lags behind the USA in the field of RDI (EC, 2017a, p. 20). 1) There are fewer young leading innovative companies (Yollies), with productivity among the worlds' best. 2) Companies in the EU are less RDI intensive. 3) The companies' sectoral dispersion is different.

Figure 2 shows how much was earned in the Horizon 2020 projects by countries (EUR million) and it is proportioned by million inhabitants, to make the results comparable. The goodness of the economy is also shown by EIS ranking. We can see that with these better projects better economies earn more money.

So, it seems to be a vicious circle, that if you start on a better ground, then you can set up better projects and with these better projects you earn more money.

The same conclusion can be drawn from other data. OECD (2016) shows that licensing income from public research is very concentrated. 10 per cent of total universities earn 86.5 per cent of the total license income earned by all universities in the sample. The numbers are pretty similar among the research organisations. The ability to earn money on knowledge shows regional variation.

Figure 2: Money earned from H2O20 (2014-2016; million EUR) / million inhabitants

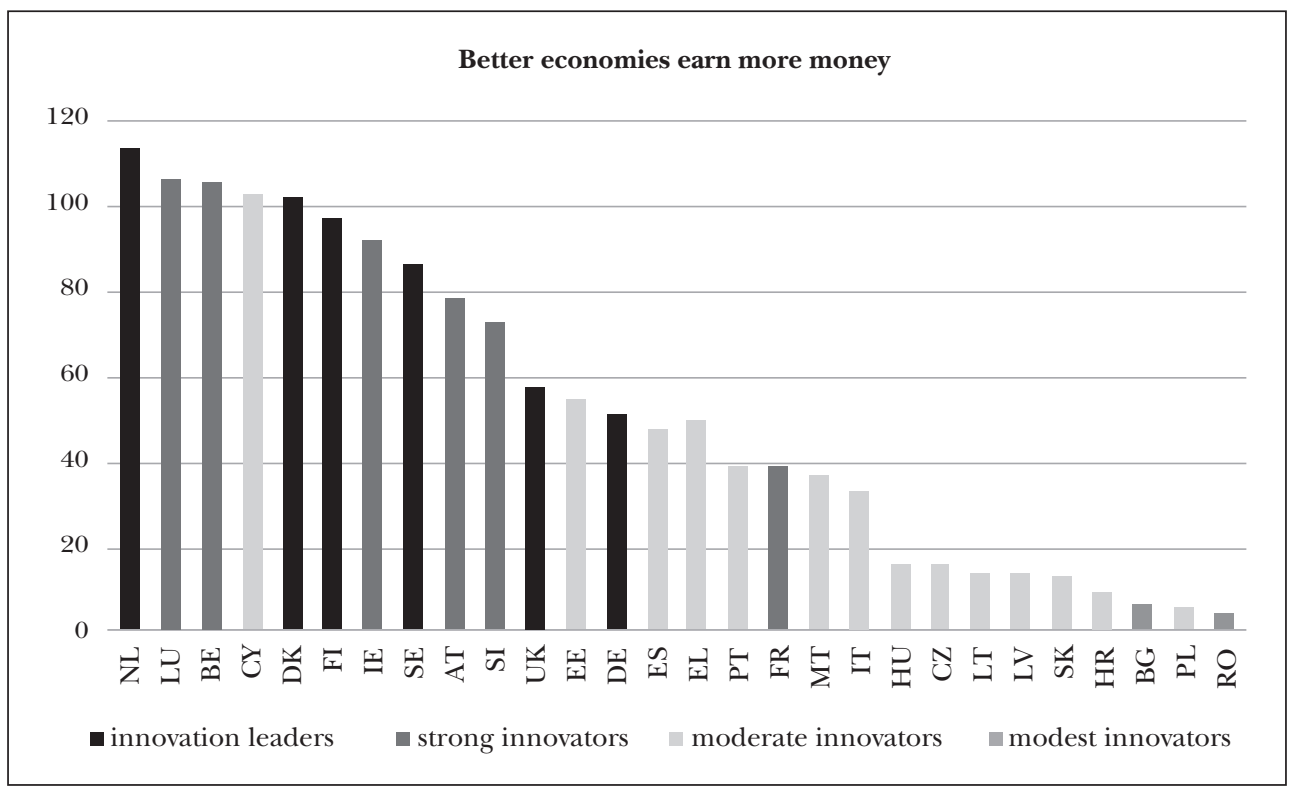

Source: Corda

This phenomenon us supported by the claims on tacit knowledge discussed above. Tacit knowledge, innovation culture and the skills needed for innovation are the concepts that help us understand this vicious circle. 


\section{Endre Spaller, László Vasa: Regional Dimension in Knowledge Production...}

It also means that in a less developed economy the projects will not be so effective, so there is a higher importance on effectiveness of project evaluation. Not to let a single good project under the threshold.

\section{THE CASE OF HUNGARY}

The Hungarian innovation system

The Hungarian government invests heavily in business R\&D. The government has the second highest share in direct support for business R\&D among 35 OECD and EU-28 countries.

\section{Structure of government funding}

The National Research, Development and Innovation Fund (NRDIF/NKFIA) integrates two funds: 1) Research and Technological Innovation Fund (KTIA) and 2) Hungarian Scientific Research Fund (OTKA). The total budget of NKFIA for 2018: HUF 82.1 billion (approx. EUR 260m). There are six operational programmes of the EU Structural Funds, co-funded by the central EU budget, that were available to the Hungarian regions from 2014 to 2020 (Ranga et al., 2015):

- Economic Development and Innovation OP (GINOP): Total budget (2014-2020) Priority 2 (Reinforcement of research, technological development and innovation): EUR 1,687.9 million

- Economic Development and Innovation OP (GINOP): Total budget (2014-2020) Priority 7 (Financial instruments to top up R\&I support): EUR 2,553.2 million

- Competitive Central Hungary OP (VEKOP): Total budget (2014-2020) Priority 1 (Improvement of companies' competitiveness and development of the knowledge economy): EUR 202.2 million

- Competitive Central Hungary OP (VEKOP): Total budget (2014-2020) Priority 2 (Financial instruments and development of services): EUR 44.1 million

- Human Resources Development OP (EFOP): Total budget (2014-2020): EUR 898.3 million; Rural Development Programme (VP): Total budget (2014-2020): EUR 25.3 million

Innovation policy

The innovation policy structure of Hungary is the keystone of the country's strategic development strategy, well-defined in line with the European Union's cohesion and innovation policies for the 2014-2020 programming period. Foreign-owned actors are eligible too for support measures available to every company operating in Hungary (HIPA, 2020). 
Figure 3: Structure of the REDD budget and GERD

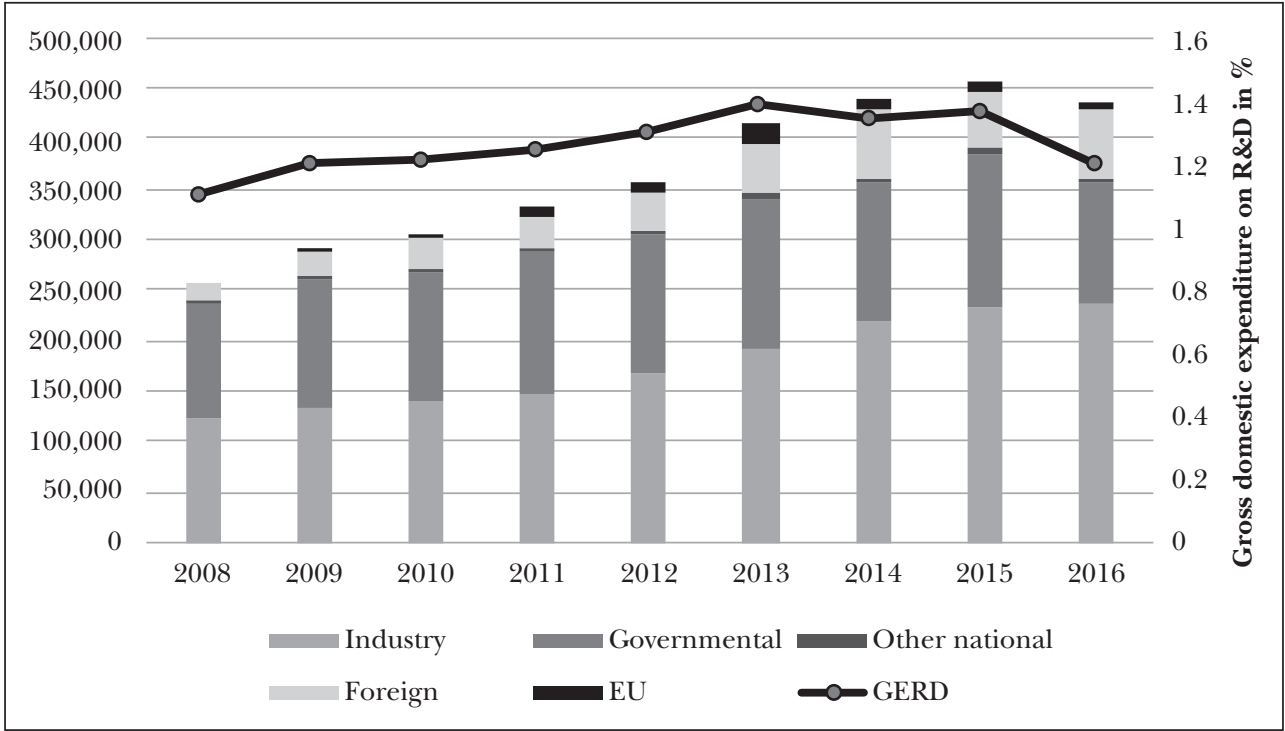

Source: CSO, 2017

National Research, Development and Innovation Strategy

The "Investment into the Future - National Research and Development and Innovation Strategy 2020" (RDI strategy) was approved by the Hungarian Government in June 2013. The aim of the strategy is to increase RDI investment, which will mobilise the Hungarian economy and strengthen its competitiveness.

\section{National Smart Specialisation Strategy}

The Smart Specialisation Strategy (S3) is developed in every Member State within the framework predefined by the EU. Hungary's smart specialisation strategy was approved in November 2014. It sets the directions for the entire country, along with which research, development and innovation are to be supported in the most sustainable way, with the greatest social profit and the promise of the best financial utilisation rate.

The Strategy sets up six sectoral and two horizontal research and innovation priorities. These priorities encompass domains, areas and economic activities where Hungary has a competitive advantage or has the potential to generate knowledge-driven growth, and are embedded in the calls of the NKFIH (National Research, Development and Innovation Office) that were published for the new programming period 2014-2020. 
Endre Spaller, László Vasa: Regional Dimension in Knowledge Production...

Sectoral priorities:

- Healthy society and well-being

- Advanced technologies in the vehicle and other machine industries

- Clean and renewable energies

- Sustainable environment

- Healthy local foods

- Agricultural innovation

Horizontal priorities:

- ICT (info-communication technologies) \& Services

- Inclusive and sustainable society, viable environment

It was partly from these antecedents that the government started to elaborate a new strategy of Industry 4.0 in 2016 (Irinyi Plan). The aim of the Irinyi Plan is to further increase the share of manufacturing in Hungarian GDP with the support of key industries: the motor vehicle manufacturing (public transport), the defence industry, the construction industry, the textile industry and medical equipment. One of the goals of the strategy is to increase the share of these industries in GDP to 30 per cent by 2020 .

\section{Business enterprise sector}

The Hungarian private sector has registered notable increases in $\mathrm{R} \& \mathrm{D}$ activities since the country's accession to the EU. The share of the business sector for the total R\&D expenditures reached 56 per cent or EUR 777m (HUF 241b) in 2016. Large companies accounted for 55.26 per cent of BERD, while SMEs depend on external sources of R\&D funding, mostly government and the EU Structural Funds. Central Hungary (including Budapest) accounts for the majority of corporate R\&D, R\&D-performing companies and patents. Pharmaceutical, ICT, machinery and automotive companies make the highest contribution to the BERD.

\section{$R \mathcal{E} D$ cooperation with EU}

European cooperation in $\mathrm{R} \& \mathrm{D}$ and Innovation is increasing in scope and importance. Most cooperative R\&D projects in Europe are carried out within the European Framework Programmes for Research and Technological Development, such as FP7 (20072013) and Horizon 2020 (2014-2020). Hungary's performance in FP7 ranked high among newly accessed Member States (EU13):

- 1,602 participants receiving EUR two hundred and ninety million

- Rank in grant awarded: sixteenth (EU28); second (EU13)

- Rank in number of participants: sixteenth (EU28); second (EU13)

- Top collaborative links: Germany; United Kingdom; Italy; France and Spain

Horizon 2020 (as of 2018)

- 632 participants receiving EUR $179.58 \mathrm{~m}$

- 200 SMEs (Small and Medium Enterprises) receiving EUR 53.58 


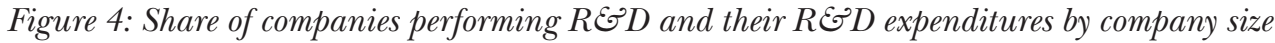

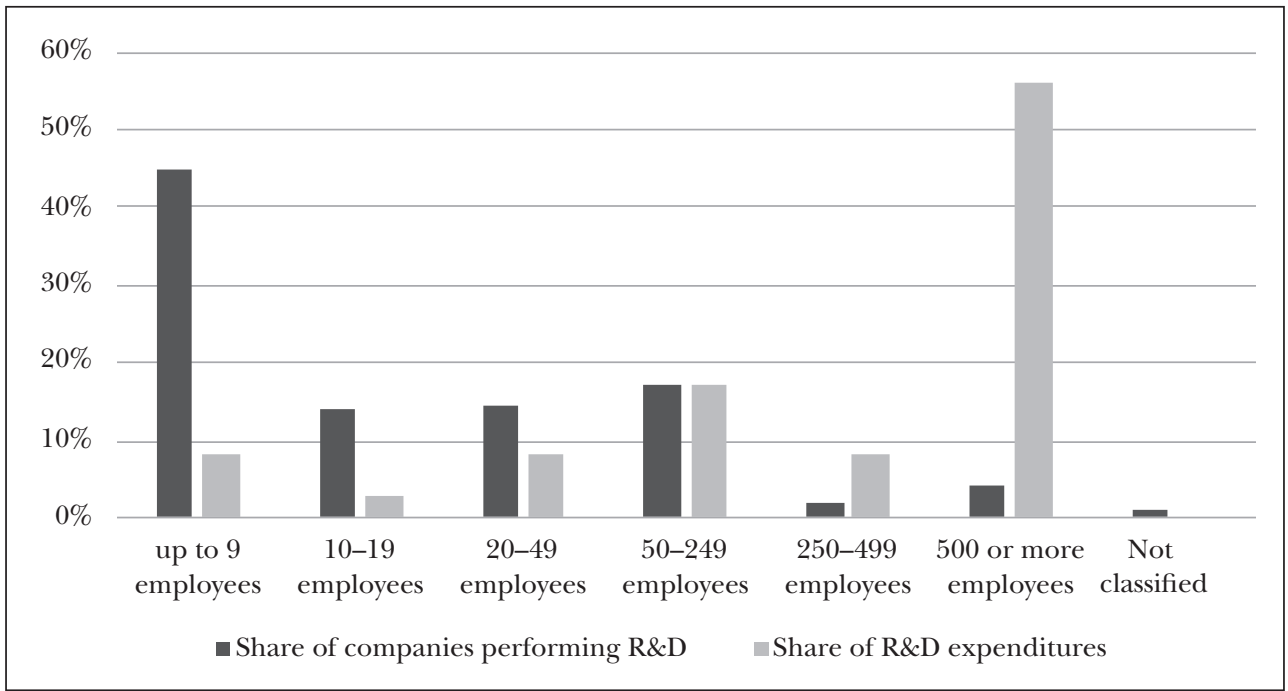

Source: EC, $2017 c$

- Ranking in grant awarded: 17th (EU28); 3rd (EU13)

- Rank in budget share: 17th (EU28); 4th (EU13)

- Top collaborative links: Germany, United Kingdom, Spain, France, and Italy

European Institute of Innovation and Technology / Knowledge and Innovation Communities

The European Institute of Innovation and Technology (EIT), established in 2008 with its headquarters in Budapest, is the first Europe-wide institution based in Hungary. The EIT is the EU's flagship institute designed to connect European business and research, and to integrate innovation, research and economic growth in Europe. The mission of EIT is carried out through the so-called Knowledge and Innovation Communities (KICs), integrating European innovation platforms of leading European stakeholders from industry, academia, and policy. KICs established with Hungarian participation:

- Climate-KIC: Central Hungary hosts a regional implementation and innovation centre

- EIT Digital has an Associate Partner Group consisting of two universities (BME and ELTE) and their industrial partners (consortium partners: Ericsson Hungary, Magyar Telekom; cooperating partners: Cisco Systems Hungary, Nokia Solutions and Networks, and General Electric Healthcare).

- KIC InnoEnergy has an Accelerator HUB in Budapest

- KIC Health has a regional office in Budapest and four Hungarian Innostar partners: GE Healthcare, Semmelweis University, University of Debrecen and the National Healthcare Service Centre 
Endre Spaller, László Vasa: Regional Dimension in Knowledge Production...

Key developments in research and innovation

Low barriers to entrepreneurship resulted in a major increase in the share of international patents from 2000 to 2019. Business enterprises can benefit from indirect support measures: tax incentives for $\mathrm{R} \& \mathrm{D}$, and through institutional funding in collaboration with public research organisations. Hungary has a proven track record of excellence in its science base and the presence of highly innovative international enterprises, and the government aims to better exploit its intellectual capital, hence the increased willingness to develop and implement demand-side innovation policy measures, such as public procurement of innovation (PPI) and pre-commercial procurement (PCP). Important progress has been made and the country now has a golden opportunity to build on the emerging collective feeling of a "new beginning" for its R\&I system. The establishment of the National Research, Development and Innovation Office (NKFIH) integrates the activities of the previous ministry departments responsible for innovation policy. The establishment of the National Research, Development and Innovation Fund (NKFIA) integrates the former Research and Innovation programmes. The establishment of the Innovation Body that consists of nine distinguished members representing both the economic and scientific spheres. New research measures were launched funded by the Operational Programmes (i.e. GINOP, VEKOP, EFOP) co-funded by the Structural Funds.

\section{Analysis of RDI sector performance in Hungary}

R\&D spending share within GDP of Hungary is 1.53 per cent in 2018. This proportion is much below the EU average. Yet this share shows quite definite shifts in the last decades compared to last decades. Among the Visegrád countries, Czech Republic precedes Hungary, but both Poland and Slovakia perform worse in this regard (see Table 1).

Table 1: Development and Research Expenditures in terms of GDP (2018)

\begin{tabular}{l|c}
\hline \multicolumn{1}{c|}{ Country } & Share (\%) \\
\hline Czech Republic & 1.93 \\
\hline Hungary & 1.53 \\
\hline Poland & 1.21 \\
\hline Slovakia & 0.84 \\
\hline
\end{tabular}

Source: Eurostat databases

In the European Union, the growth of R\&D expenditures (in defined in terms of GDP) is essential key target. The EU average target is reaching 3.0 per cent in proportion of GDP for 2020; whereas Hungary targeted 1.8 per cent. Considering the fields of science and technology, the big picture of the $\mathrm{R} \& \mathrm{D}$ sector is quite positive, however, also weaknesses can be detected: productivity and patent activity are the outliners, whereas $R \& D$ intensity, the value added of the manufacturing and high tech inten- 
sity are strengths of the Hungarian economy. Based on the analysis of the European Innovation Scoreboard, the Hungarian Innovation Index was 72.3 in 2019 which is substantially better than in 2012 (64.8). Based on the surveys, among strengths we can identify the innovation friendly environment, the employment and sales impacts innovation and broadband penetration. Regarding the sectoral distribution of innovation activities, we can observe that pharmaceutical sector shows the share of innovative firms highest (63.9 per cent), while the IT and communication sector ( 50.3 per cent) and the oil refinery sector (50 per cent) can be regarded innovation-intensive economic sectors as well. Average levels are to be found around 30 per cent, the share of innovative firms is above this level in the automotive industry (42.1 per cent), chemical sector ( 44.7 per cent) and finances, insurance sector (43.6 per cent),just to name a few of the most important sectors (Moldicz, 2020).

Figure 5: European Innovation Scoreboard 2020

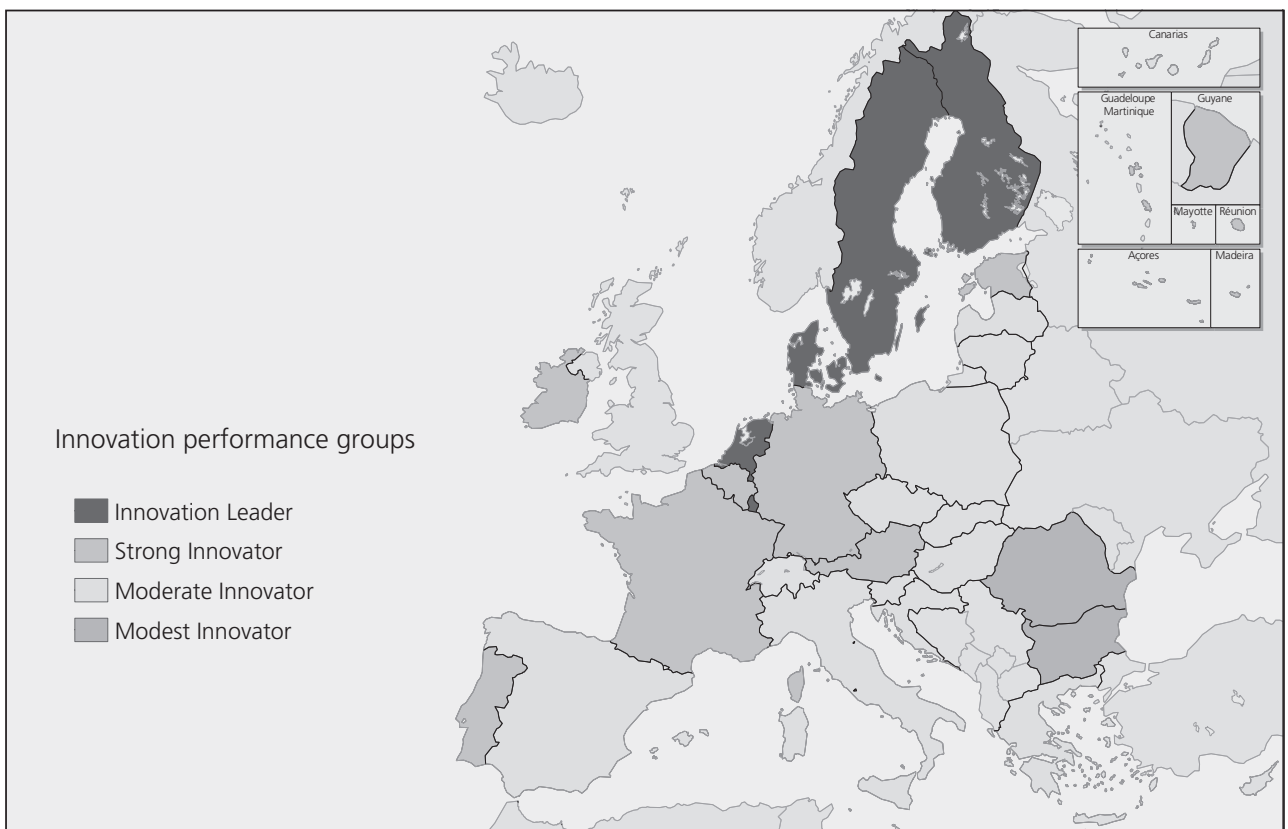

Source: EC, 2020

Based on the European Innovation Scoreboard 2020, employment impacts, sales impacts and innovation-friendly environment are the strongest innovation dimensions in Hungary. Performance is highest for employment in fast-growing enterprises of innovative sectors, medium and high-tech product exports, non-R\&D innovation expenditures, and broadband penetration. Innovators, human resources and finance and support are the weakest innovation dimensions. Hungary's lowest indicator scores are on Design applications, SMEs innovating in-house, SMEs with marketing or organisational innovations, and R\&D expenditures in the public sector. 


\section{Endre Spaller, László Vasa: Regional Dimension in Knowledge Production...}

More than 50 per cent of the $\mathrm{R} \& \mathrm{D}$ spending inflow from the corporate sector in Hungary, whereas the public budget spending typically make up around one-third of the total expenditures. Approximately 17 per cent of the expenditures are received from international sources (as against 15 per cent in 2018). The main actors of innovation are the private companies: more than 70 per cent of the research and development funds are performed by them; both the Hungarian higher education institutions and research institutes spend 13-13 per cent of the total sum on research and development. If we take the source distribution of the corporate research and development expenditures into consideration, we can observe that 70 per cent are from the corporate sector, 17 per cent from international sources and only 13.6 per cent from the public budget. However, it is a remarkable fact that micro and small enterprises (in European categorisation enterprises, where the number of workforce is less than 50) mainly rely on government funds (37.6 per cent) in their research and development spending, while the same ratio is 25.5 per cent in the case of mediumsize enterprises (based on the categorisation the number of employees is between 50 and 249) and 3.1 per cent at large enterprises (number of employees is more than 250). Based on strategy of science and technology of Hungary the government established the National Research Development and Innovation Office (NRDIO) in 2014. The NRDIO established the NRDI Fund. The fund is financed from several sources: the contribution of the central budget and the so-called 'innovation contribution' of the companies. The innovation contribution is built in the tax system of Hungary and the aim is to support the technological development of the Hungarian economy in a sustainable way. Another special purpose of the fund is to supplement and balance the EU funds.

EU's structural funds focusing on the support of less developed regions in Europe. In the case of Hungary, less developed regions are in the rural areas, while more than two-third of the Hungarian research and development facilities and activities are to be found in the central region (Budapest and Pest county); where GDP per capita is above the EU level. (2017: 139.7\%). So, the amount of available funds is reduced in the region where the potential for research and innovation is given.

Regarding international relations and cooperation, the mission of the NRDIO is to coordinate the EU Framework Programme for Research and Development Horizon 2020, which is an 80 billion euros fund available between 2014 and 2020. In the institutional framework of the NRDIO, the so-called National Contact Points were established so that they inform and advise potential grant applicants. The NRDIO also represents Hungarian interests in several strategic, decision-making bodies of the "Horizon" programme, the representation of Hungarian interests in the bodies is supported by a network of specialists and experts.

In the case of a single country we can examine three things:

- Did the performance indicators grow?

- Did the country's economy converge to a bigger group of countries or did the advantage remain?

- Did the regions of that country converge? 
The performance indicators have been growing in the last decade (2010-2019). The gross expenditure on R\&D (GERD) was growing from EUR 1.13 to 2.16 billion. The number of R\&D places (private and public) has increased from 2983 to 3555. The number of R\&D personnel has increased from 53,991 to 70,589. There are not any performance indicators which have not been growing significantly. These indicators are just quantity indicators.

Measuring the quality of the R\&D is always harder especially in the business sector, because most of the performance indicators express cost and not result. What we can say here is that the growth of $R \& D$ sector (the source of expenditure) comes from both the public and private sector, but the proportion of the business sector has increased from 47 per cent in 2010 to 52 per cent in 2019. While the public R\&D sector (universities, research institutes) are not able to survive without governmental funds, we can hope that the private leg of this sector is less dependent from the public expenditures.

In terms of convergence to the EU countries, it seems clear that there was a kind of convergence; however the Hungarian $\mathrm{R} \& \mathrm{D}$ is still a rounding error in the EU landscape (Figure 6).

Figure 6: Ratio of Hungarian GERD to EU GERD

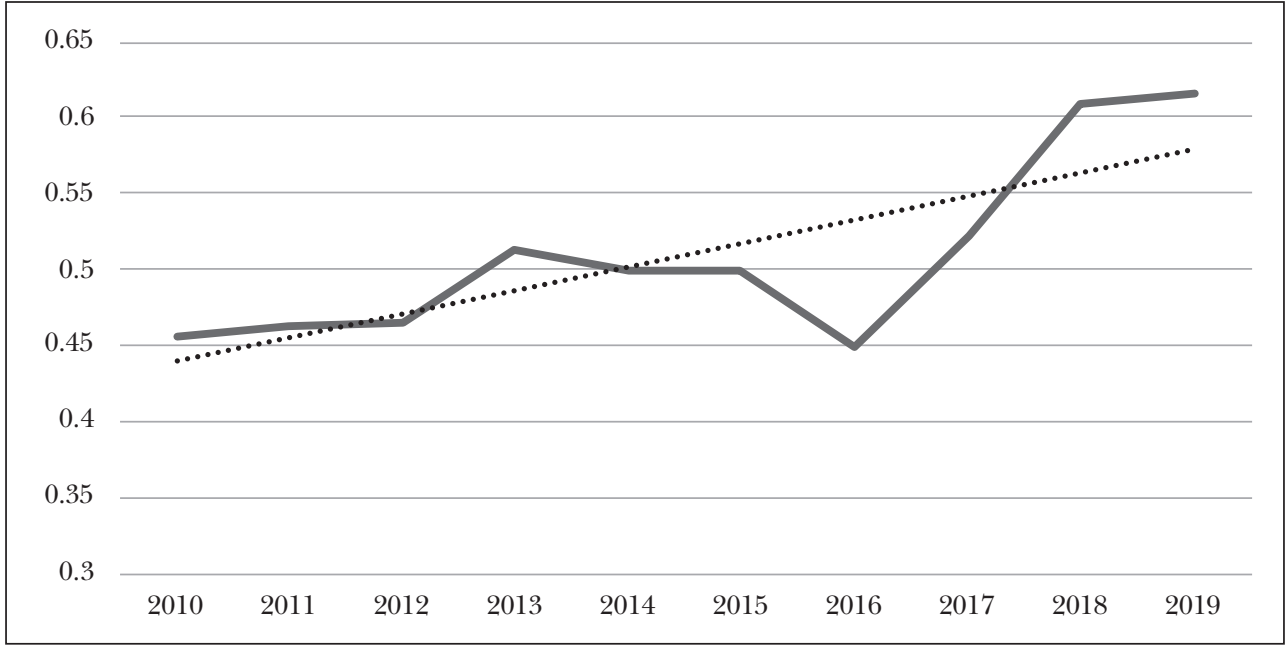

Source: Eurostat

In the last decade the Hungarian GERD almost doubled. It has increased from 1.13 to 2.16 billion EUR. Meanwhile the EU GERD changed from EUR 247 million to EUR 351 billion. The trend line shows a convergence however it is not linear.

We concluded the previous chapter with confirming the theory of tacit knowledge with data. Thus, we expect that the places where R\&D plays an important role should be play even higher role after a decade. We saw the concentration of the RDI processes. On the Figure 3 we see that a convergence is still possible. 


\section{Endre Spaller, László Vasa: Regional Dimension in Knowledge Production...}

A survey of the convergence by Hungarian regions gives a mixed picture. We collected the GERD of the region in 2010 and 2019, and we divided them. The number that we get shows how much more important the R\&D is today than it was a decade ago in GDP. The basis was not even. A decade ago there were counties with almost no R\&D sector (e.g. Tolna: 0.1\%), and counties with relative high GERD (e.g. Csongrád: $1.9 \%$ ). Hungarian GDP was growing faster than the EU average. In the whole economy there was a convergence. There were counties which performed a high GDP growth so a similarly growing $\mathrm{R} \& \mathrm{D}$ sector plays a similar proportion.

Table 2: How much more important is the REंD sector today in the economy than it was a decade ago? (GERD\% 2019 / GERD\% 2010)

\begin{tabular}{l|c}
\hline \multicolumn{1}{c|}{ Region } & \\
\hline Central Hungary & 1.4 \\
\hline Western Transdanubia & 1.4 \\
\hline Central Transdanubia & 2.1 \\
\hline Southern Transdanubia & 1.4 \\
\hline Northern Hungary & 1.1 \\
\hline Northern Great Plain & 0.9 \\
\hline Southern Great Plain & 1.2 \\
\hline Average & 1.3 \\
\hline
\end{tabular}

Source: Authors' elaboration based on data by the Hungarian Central Statistical Office (KSH)

The Table 2 shows that today the R\&D sector plays 30 per cent higher role in the economy than a decade ago, so the convergence of it was higher than the convergence of GDP. It is really interesting that the central and western regions all were growing more than the average and all the eastern regions were growing under the average.

To conclude this chapter, we see that the Hungarian R\&D economy was able to catch up to the EU average. The main performance indicators have been growing constantly. Among the regions not only the capital and the central region was able to make its R\&D industry grow but a number of regions.

\section{CONGLUSIONS}

There were two contradicting theories to be tested on H2020 data. One of them claims that knowledge flow across regions is limited. This is due to the tacit part of the knowledge. The other argues that one can buy innovation results by funding innovation, and this is a good way of reducing regional gaps.

Our data on the EU R\&D performance confirms the first one. Thus, one cannot simply buy innovation results for money. Less developed countries need to add something to the research funding system that ensures the flow and accumulation of tacit knowledge. If policy-makers want to attach GDP growth expectations to the RDI 
Civic Review · Vol. 16, Special Issue, 2020

funds, they should incorporate it to the rationale of public support, and the elimination of the obstacles to the flow of tacit knowledge.

In the regions of Hungary, the other theory was found to better describe the data. Convergence is possible, and convergence is not even across the country. Thus the contradiction between the two theories do not seem to have got any closer to a resolution. In the authors' opinion, the Hungarian RDI is sufficiently embedded in the European RDI industry to be able to absorb tacit knowledge.

However, this study has revealed the shortages and missing elements that prevent the dissolution of contradiction between the two theories. The nature of tacit knowledge, or in other words, the evolution of an innovation culture needs to be understood more thoroughly. Thus, the turning of the quantity of RDI funds into quality over time needs to be detected.

The synthesis of the two theories would help RDI funding agencies and policymakers to understand how RDI funds can best contribute to economic convergence.

\section{REFERENCES}

Asheim, B. T. and Gertler, M. S. (2005): The geography of innovation. In: Fagerberg, J. and Mowery, D. C. (eds.): The Oxford Handbook of Innovation. Oxford University Press, Oxford.

Bornmann, L. (2013): What is Societal Impact of Research and How Can It Be Assessed? A Literature Survey. Journal of the American Society for Information Science and Technology, Vol. 64, No. 2, 217-233, https:// doi.org/10.1002/asi.22803.

Chandra V.; Eröcal, D.; Padoan P. C. and Primo Braga, C. A. (2010): Innovation and Growth. Chasing a Moving Frontier. World Bank, OECD, Paris.

CSO (2017): A kutatás-fejlesztési ráforditások (falakon belüli) pénzügyi forrásai szektoronként [Financial sources of research and development expenditures (within the walls) in a sector breakdown]. www.ksh.hu/docs/ hun/xstadat/xstadat_eves/i_ohk004a.html.

EC (2014): Research and Innovation as Sources of Renewed Growth. SWD(2014) 181 final, European Commission.

EC (2017a): The Economic Rationale for Public RE्I Funding and its Impact. European Commission DG Research and Innovation.

EC (2017b): FAB-LAB-APP. Investing in the European Future We Want. European Commission, Brussels.

EC (2017c): Peer Review of the Hungarian Research and Innovation system. Horizon 2020 Policy Support Facility. European Commission, Brussels.

EC (2020): European Innovation Scoreboard 2020. European Commission, https://ec.europa.eu/docsroom/ documents/42981.

Filep, B.; Tamándl, L.; Rámháp, Sz. and Kovács, Zs. (2012): The Economical and Social Impact of Széchenyi István University (Gyôr, Hungary) on Regional Development. In: Business and Management 2012: 7th International Scientific Conference. Gediminas Technical University Press, Vilnius.

Filep, B. (2014): A nagyvárosok az európai és a magyar területi politikában [Metropolitan areas in the European and Hungarian regional policies]. Publikon Kiadó, Budapest.

Guan, J. C.; Zuo, K. R.; Chen, K. H. and Yam, R. (2016): Does Country-Level R\&D Efficiency Benefit from the Collaboration Network Structure? Research Policy, Vol. 45, No. 4, 770-784, https://doi.org/10.1016/j. respol.2016.01.003.

Hather, G. J. et al. (2010): The United States of America and Scientific Research. PLoS ONE, Vol. 5, No. 8, https://doi.org/10.1371/journal.pone.0012203.

HIPA (2020): Introduction to the Hungarian RE्乛D Sector.www.investhipa.hu/images/hipa_kiadvany_intro_innovation_201808.pdf. 


\section{Endre Spaller, László Vasa: Regional Dimension in Knowledge Production...}

Jaruzelski, B.; Dehoff, K. and Bordia, R. (2005): Money Is Not Everything. In: Strategy+business. Winter, No. 41, www.urenio.org/wp-content/uploads/2009/01/global-innovation-1000-2005.pdf.

Jones, C. I. (1995): R\&D-Based Models of Economic Growth. Journal of Political Economy, Vol. 103, No. 4, 759-784, https://doi.org/10.1086/262002.

Lengyel, I. (2010): Regionális gazdaságfejlesztés. Versenyképesség, klaszterek és alulról szervezôdố stratégiák [Regional economic development]. Akadémiai Kiadó, Budapest.

Macilwain, C. (2010): Science Economics: What Science is Really Worth. Nature, No. 465, 682-864, https:// doi.org/10.1038/465682a.

Moldicz, Cs. (2020): Hungary Economy Briefing: Science and Technology Innovation Mechanisms in Hungary. Weekly Briefing of China-CEE Institute, Vol. 32, No. 2, 1-5.

OECD (2016): OECD Science, Technology and Innovation Outlook 2016. Policy Profile. OECD Publishing, Paris.

Ranga, M.; Ortega-Argiles, R. and Bartzokas, A. (2015): Pre-Peer Review of the Hungarian Research and Innovation system. Horizon 2020 Policy Support Facility. European Commission, https://rio.jrc.ec.europa.eu/ sites/default/files/report/HU\%20PPR\%20FINAL\%20for\%20PUBLICATION_0.PDF

Rechnitzer, J. (ed.) (1994): Fejezetek a regionális gazdaságtan tanulmányozásához [Chapters for studying regional economics]. MTA - Regionális Kutatások Központja, Pécs-Gyôr.

Rechnitzer, J.; Berkes, J. and Filep, B. (2019): The Most Important City Development Initiatives of Hungary. Regional Statistics, Vol. 9, No. 2, 20-44, https://doi.org/10.15196/RS090204

Romano, L. and Trau, F. (2017): The Nature of Industrial Development and the Speed of Structural Change. Structural Change and Economic Dynamics, Vol. 42, 26-37, https://doi.org/10.1016/j.strueco.2017.05.003.

Romer, P. M. (1990): Human Capital and Growth: Theory and Evidence. Carnegie-Rochester Conference Series on Public Policy: Unit Roots, Investment Measures and Other Essays, Vol. 32, 251-286.

Shibata, N., Kajikawa, Y., Takeda, Y. and Matsushima, K. (2008): Detecting Emerging Research Fronts Based on Topological Measures in Citation Networks of Scientific Publications. Technovation, Vol. 28, No. 11, 758-775, https://doi.org/10.1016/j.technovation.2008.03.009.

Szirmai, V. (2005): A városkutatások továbbfejlesztésének szempontjai: az európai várostudományok jövôje [Aspects for the further development of urban research: the future of European urban sciences]. Tér és Társadalom, Vol. 19, No. 3-4, 43-60.

Toth-Haasz, G.; Baracskai, Z. and Dôry, T. (2019): Understanding Aspirations: R\&D Project Evaluation by Knowledge Based Systems. In: Muslim, A.; Aleksic, A. and Dukic, D. (eds.): Economic and Social Development (Book of Proceedings). 37th International Scientific Conference on Economic and Social Development: Socio Economic Problems of Sustainable Development. Baku, 828-836.

Vanino, E.; Roper, S. and Becker, P. (2019): Knowledge to Money: Assessing the Business Performance Effects of Publicly-Funded R\&D Grants. Research Policy, Vol. 48, No. 7, https://doi.org/10.1016/j.respol.2019.04.001. 